\title{
PENGARUH PERMAINAN BOLA PANTUL TERHADAP KEMAMPUAN SERVIS ATAS BOLA VOLI PADA SISWA SMPN 2 NANGA PINOH
}

\author{
Rapi Turiansyah ${ }^{1}$, Eko Rudiansyah ${ }^{2}$, Suyatmin ${ }^{3}$ \\ ${ }^{1}$ Mahasiswa Program Studi Penjaskesrek STKIP Melawi \\ ${ }_{2,3}$ Dosen STKIP Melawi
}

J1. RSUD Melawi km. 04 Kec. Nanga Pinoh Kab. Melawi Kalimantan Barat

Email: rapituriansyah12@gmail.com, ekorudiansyah90@gmail.com, Suyatminuny@gmail.com

\begin{abstract}
The purpose of this study was to determine effect of reflective ball media on the ability to servis on volleyball game of state juniot high school students Nanga Pinoh. The design used in the study was One Group Pretest-Posttest Design ", namely the research design that contained pretest before been given treatment and posttest after be treated. Data analysis techniques used the liliefors normality test, looked for averages and product moment correlation tests to test hypotheses. The calculation results above show that the calculated value (rxy) was 0.9893 and rtable (see table price r product moment correlation with $n=19$ with a $95 \%$ confidence interval, and a $5 \%$ significance level), then $r_{\text {table }} 0.456$, so it can be concluded that $r_{\text {count }}>r_{\text {table }}$, or 0.9893 > 0, 456 means Ha was accepted and Ho was rejected. So there was a significant relationship or influence between the game of bounce ball with the ability to service volleyball. Based on the results of the study it can be concluded that there was an influence of the media of bounce ball on the ability to service the volleyball game for students of Nanga Pinoh State 2 Middle School Student.
\end{abstract}

Keywords: Volleyball, Bounce Ball Game, Upper Service Technique.

Abastrak: Tujuan penelitian adalah untuk mengetahui pengaruh permainan bola pantul terhadap kemampuan servis atas pada permainan bola voli siswa SMPN 2 Nanga Pinoh. Desain yang digunakan dalam penelitian adalah One Group Pretest-Posttest Design”, yaitu desain penelitian yang terdapat pretest sebelum diberi perlakuan dan posttest setelah diberi perlakuan. Teknik analisis data menggunakan uji normalitas liliefors, mencari rata-rata dan uji korelasi product moment untuk menguji hipotesis. Hasil perhitungan dari data penelitian diperoleh bahwa nilai rhitung (rxy) adalah 0,9893 dan nilai $r_{\text {tabel }}$ (lihat tabel harga $r$ korelasi product moment dengan $n$ $=19$ dengan interval kepercayaan 95\%, dan taraf signifikan 5\%) maka $r_{\text {tabel }}$ 0,456, jadi dapat disimpulkan bahwa $r_{\text {hitung }}>r_{\text {tabel}}$, atau 0,9893 $>0,456$ berarti Ha diterima dan Ho ditolak. Jadi terdapat pengaruh yang signifikan antara permainan bola pantul dengan kemampuan servis atas bola voli. Kesimpulannya adalah terdapat pengaruh permainan bola pantul terhadap kemampuan servis atas pada permainan bola voli pada siswa SMPN 2 Nanga Pinoh.

Kata Kunci: Bola Voli, Permainan Bola Pantul, Teknik Servis Atas. 
$\mathrm{P}$ restasi yang pernah diraih tim ekstrakurikuler bola voli SMPN 2 Nanga Pinoh adalah juara 1 umum antar sekolah Sekabupaten Melawi pada tahun 2017, setelah itu pada tahun berikutnya mengalami penurunan yaitu menduduki peringkat 4. Menurut pelatih tim ekstrakurikuler bola voli SMPN 2 Nanga Pinoh, meskipun berprestasi tim pada sekolah tersebut, namun akhir-akhir ini mengalami penurunan teknik dalam bermain bola voli yakni memiliki kelemahan pada servis atas, sehingga kelemahan tersebut membuat tim tersebut jarang masuk dalam melakukan servis atas, karena servis adalah serangan pertama pada saat pertandingan berlangsung dan servis atas mempengaruhi dalam permainan bola voli. Penurunan prestasi ini bisa disebabkan oleh beberapa faktor yang kurang maksimal, diantaranya latihan fisik, latihan teknik, latihan taktik, maupun latihan mental.

Meningkatkan keterampilan siswa tersebut tentu seorang guru atau peneliti harus memahami karakter siswa terlebih dahulu, kelemahan dan kekurangan siswa, sehingga dengan demikian guru dapat mengambil langkah atau cara untuk meningkatkan, melatih dan berupaya untuk memperbaiki terutama dalam proses belajar mengajar di sekolah. Untuk meningkatkan kemampuan servis tersebut perlu dikuasai teknik-teknik dalam meningkatkan power dalam latihan servis dalam permainan bola voli. Penguasaan teknik dasar sangat penting agar bias melakukan permainan bola voli dengan baik. Untuk menguasai teknik-teknik dasar dalam permainan bola voli hendaknya pembina memberikan pengetahuan dan mengajarkan teknik-teknik dasar permainan bola voli dengan baik dan benar. Hal ini dirasakan sangat penting karena merupakan hal mendasar yang harus diketahui dan dikuasai oleh siswa.

Hasil observasi pada tanggal 19 september 2018 pada kegiatan ekstrakurikuler ditemukan bahwa siswa SMPN 02 Nanga Pinoh dalam bermain bola voli masih banyak mengalami kekurangan. Dari beberapa teknik dasar permainan bola voli seperti pasing, servis, smas, dan block. Dari beberapa teknik dasar tersebut ada salah satu teknik dasar masih banyak siswa yang mengalami kesulitan yaitu servis atas. Masih banyak siswa yang gerakannya salah saat melakukan servis atas, misalnya posisi badan, kaki dan tangan. kurangnya power (kekuatan) saat memukul bola sehingga tidak melewati net. Kurangnya keseriusan dalam melakukan servis atas sehingga memukul bola tidak maksimal. Siswa melakukan servis atas sambil bermain sehingga mengganggu konsentrasi saat memukul bola. Nilai rata-rata siswa yang diperoleh pada saat observasi adalah 46,44 dari 30 siswa. Solusi yang digunakan untuk permasalahan tersebut adalah dengan 
permainan bola pantul yaitu memantulkan bola kedinding.

Kesenjangan dari permasalahan yang telah dijelaskan tersebut peneliti tertarik untuk melakukan penelitian yaitu Pengaruh Permainan Bola Pantul Terhadap Kemampuan Servis Atas Bola Voli. Peneliti yakin bahwa masalah servis hingga saat ini masih menjadi perhatian serius bagi para pelatih ataupun guru pendidikan jasmani dalam upaya meningkatkan keterampilan para pemain dalam bermain bola voli. Harapan peneliti dari penelitian ini ialah siswa SMPN 2 Nanga Pinoh tidak hanya mampu memahami dan menguasai teknik dasar bermain voli terutama servis atas namun siswa juga mampu bermain dan bekerja sama dengan baik dengan saat bermain voli dilapangan. Tujuan dari penelitian ini adalah untuk mengetahui apakah terdapat pengaruh permaian bola pantul terhadap kemampuan servis atas pada permainan bola voli siswa SMPN 2 Nanga Pinoh.

Menurut Sukadiyanto (2002: 05) istilah latihan berasal dari kata dalam bahasa Inggris yang dapat mengandung beberapa makna seperti: practice, exercises, dan training. Pengertian latihan yang berasal dari kata practise adalah aktivitas untuk meningkatkan keterampilan (kemahiran) berolahraga dengan menggunakan berbagai peralatan sesuai dengan tujuan dan kebutuhan cabang olahraganya.
Pengertian latihan yang berasal dari kata exercises adalah perangkat utama dalam proses latihan harian untuk meningkatkan kualitas fungsi sistem organ tubuh manusia, sehingga mempermudah olahragawan dalam penyempurnaan geraknya. Exercises merupakan materi latihan yang dirancang dan disusun oleh pelatih untuk satu sesi latihan atau satu kalitatap muka dalam latihan, misalnya susunan materi latihan dalam satu kali tatap muka pada umumnya berisikan materi, antara lain: (1) pembukaan/pengantar latihan, (2) pemanasan (warming-up), (3) latihaninti, (4) latihan tambahan (suplemen), dan (5) cooling down/penutup.

Latihan yang berasal dari kata training adalah penerapan dari suatu perencanaan untuk meningkatkan kemampuan berolahraga yang berisikan materi teori dan praktek, metode, dan aturan pelaksanaan sesuai dengan tujuan dan sasaran yang akan dicapai. Latihan itu diperoleh dengan cara menggabungkan tiga faktor yang terdiri atas intensitas, frekuensi, dan lama latihan. Walaupun ketiga faktor ini memiliki kualitas sendiri-sendiri, tetapi semua harus dipertimbangkan dalam menyesuaikan kondisi saat latihan.

Latihan akan berjalan sesuai dengan tujuan apabila diprogram sesuai dengan kaidah-kaidah latihan yang benar. Program latihan tersebut mencakup segala hal mengenai takaran latihan, frekuensi latihan, 
waktulatihan, dan prinsip-prinsip latihan lainnya. Program latihan ini disusun secara sistematis, terukur, dan disesuaikan dengan tujuan latihan yang dibutuhkan.

Permainan bola voli termasuk permainan yang terpopuler di masyarakat. Permainan ini hanya membutuhkan lahan kosong dan tidak mengeluarkan biaya yang banyak. Sehingga banyak sekali masyarakat yang menyukai dan melakukan olahraga ini. Bola voli merupakan permainan beregu yang terdiri atas enam orang pemain pada masing-masing regu. Tujuan permainan bola voli adalah pemain mengirimkan bola melewati net dan jatuh di dalam batas lapangan lawan.

Permainan bola voli adalah suatu cabang olahraga dengan ciri gerakan memvoli bola di udara. Bola hilir mudik melalui net dengan maksud menjatuhkan bola di dalam petak lapangan lawan sebanyak mungkin. Memvoli dan memantulkan bola ke udara dapat menggunakan bagian tubuh mana saja, asalkan sentuhan atau pantulannya harus sempurna. Permainan bola voli dapat dimainkan oleh anak-anak hingga orang dewasa, baik wanita maupun pria. Permainan bola voli dapat digunakan sebagai sarana pembentukan individu, baik perkembangan jasmani maupun rohani. Prestasi pemain bola voli akan baik jika jasmani dan rohani saling terkait dalam gerakan-gerakan bermain.
Permainan bola voli awalnya dimainkan untuk aktivitas rekreasi, yaitu bagi para usahawan. Permainan bola voli kemudian berkembang dan menjadi populer di daerah pariwisata dan dilakukan di lapangan terbuka, tepatnya di Amerika Serikat ketika musim panas tiba. Selanjutnya permainan bola voli berkembang di kanada. Melalui gerakan internasional YMCA, permainan bola voli meluas ke negara lainnya, yaitu Kuba, Puerto Rico, Uruguay, dan republik Rakyat Tiongkok serta Jepang (Muhajir, 2016: 26).

Prinsip permainan bola voli adalah memainkan bola dengan divoli (dipukul dengan anggota badan) dan berusaha menjatuhkan bola kelapangan lawan dengan menyebrangkan bola lewat atas net serta mempertahankan agar bola tidak jatuh dilapangan sendiri. Lapangan permainan bola voli berbentuk empat persegi panjang dengan ukuran 18 meter x 9 meter, lapangan dibagi menjadi 2 ukuran yang sama oleh sebuah garis tengah yang diatasnya dibentangkan net dengan ketinggian 2,43 meter untuk pemain putra dan 2,24 meter untuk pemain putri, dan terdapat dua garis serang pada masing-masing petak yang berjarak 3 meter dari garis tengah.

Jumlah pemain dalam setiap regu yang sedang bermain adalah 6 orang dan 8 orang lagi sebagai cadangan. Penilaiannya regu yang gagal menyeberangkan bola (mati) lawan dapat nilai (rally point), dan servis 
dilakukan bagi regu yang memperoleh nilai serta dilakukan dibelakang garis lapangan sendiri. Setiap regu tidak diperkenankan memainkan bola lebih dari tiga kali sentuhan sebelum bola melewati net, kecuali bendungan atau block. Selama bola dalam permainan semua pemain tidak boleh menyentuh net dan melewati garis tengah masuk ke daerah lawan.

Teknik servis atas pada permainan bola voli adalah teknik dasar yang paling awal dipelajari dan juga teknik yang banyak diajarkan pada pemula. Servis adalah suatu teknik dalam permainan bola voli untuk melontarkan bola dari luar garis belakang area lapangan sebuah tim melewati atas jaring ke area lapangan tim lawan. Servis ini merupakan salah satu teknik dasar yang harus dimilki oleh seorang pemain bola voli. Karena sebuah pertandingan bola voli akan selalu diawali dari sebuah servis bola.

Servis atas adalah sebuah tindakan memukul bola dengan ayunan tangan yang diarahkan dari atas. Saat melakukan pukulan diikuti dengan lompatan dengan bertujuan agar bisa mengerahkan tenaga dan memukul bola dengan keras sehingga bisa melesat dengan kecepatan tinggi. Dari pengertian ini dapat disimpulkan, seperti yang telah dijelaskan di atas bahwa teknik servis bola voli tidak semata-mata mengawali permainan, tapi bisa berupa serangan awal agar bisa mendapatkan point. (Muhammad
Teknik servis ini sangat berguna kala memulai permainan bola voli atau melakukan putaran/babak baru. Berikut ini adalah tata cara melakukan servis atas (Muhajir, 2016: 29) yakni. Berdiri dengan kaki kiri di depan, kaki kanan di balakang, dan kedua lutut agak ditekuk. Tangan kiri memegang bola, tangan kanan di samping kepala dengan siku dibengkokkan. Telapak tangan dihadap ke depan. Lambungkan bola dengan tangan kiri ke samping atas kanan depan dengan tidak terlalu tinggi. Setelah bola melambung setinggi kepala, tangan kanan segera memukul bola pada bagian tengah belakang. Pada saat perkenaan tangan dengan bola harus diusahakan tidak ada gerakan pergelangan tangan. Pukulan harus dilakukan dengan cepat dan setelah bola dipukul, gerakan tangan segera ditahan. Setelah memukul bola lanjutkan dengan melangkahkan kaki kanan kedepan dan terus masuk kelapangan permainan untuk mengambil sikap siap dalam posisinya.

Permainan bola pantul adalah suatu permainan dalam bola voli yang dimodifikasi dengan sedemikian rupa sehingga memicu semangat dan kesenangan peserta yang bertujuan untuk meningkatkan kemampuan servis pada siswa permainan tersebut. Seperti dalam bukunya. Durrwachter (1990: 32) menyebutkan salah satu bentuk latihan bola voli adalah permainan tenis atau permainan bola pantul. Syaleh, 2017: 24) 
Bola yang datang melewati atas net yang dibentangkan mula-mula harus terpantul dulu ke dinding setelah itu dilakukan servis melewati bentangan net ke arah teman di lapangan seberang, begitu seterusnya. Lebih jelas Durrwachter (1990: 32) menjelaskan bahwa permainan ini dimaksudkan untuk melatih rentang tungkai dan tubuh pada saat melakukan servis, serta mengajarkan memantulkan bola kedinding. Bentuk latihan yang digunakan dalam permainan ini adalah latihan dengan permainan bola pantul, karena dengan menggunakan permainan siswa akan termotivasi dan lebih giat untuk mengikuti kegiatan bola voli di sekolah. Berdasarkan karakteristik permainan tenis atau permainan bola pantul di atas, maka dapat diidentifikasi kelebihannya.

Permainan bola pantul memiliki beberapa bentuk, akan tetapi peneliti menggunakan salah satu pendapat menurut Durrwachter (1990: 56) bentuk-bentuk permainan bola pantul untuk latihan gerak dasar servis adalah sebagai berikut: Setiap siswa menjatuhkan bola dari setinggi atas kepala, lalu dengan cepat lengan yang terentang keatas dalam posisi seperti menyemes disodorkan pantulan ke dinding bola yang dilambungkan ke atas. Cara melakukanya adalah siswa melakukan permainan pantulan sendiri-sendiri yaitu dengan cara siswa menjatuhkan bola dari setinggi atas kepala, lalu dengan cepat lengan yang terentang ke atas dalam posisi smash disodorkan ke dinding bola yang dilambungkan ke atas dan seterusnya.

Siswa melakukan servis kedinding, biarkan bola terpantul kemudian melakukan servis kembali dan seterusnya. Cara melakukanya adalah siswa melakukan servis sendiri ke arah dinding dan seterusnya. Siswa melakukan servis sepuluh kali berturut-turut. Bola boleh terpantul ke lantai dengan teknik dasar servis. Cara melakukanya adalah siswa melakukan servis sendiri dengan serempak yaitu melakukan servis sepuluh kali berturut-turut dengan bola boleh terantul ke lantai. Siswa melakukan servis terus-menerus ke dinding, bola yang terpantul boleh menyentuh lantai dan melambung lagi sebelum servis berikutnya. Cara melakukanya adalah siswa menghadap ke dinding kemudian siswa melakukan servis terus-menerus ke dinding dengan catatan bola boleh menyentuh lantai atau bola dibiarkan memantul ke lantai sebelum melakukan servis berikutnya.

Bentuk-bentuk permainan di atas menekankan model permainan dengan materi servis, dalam permainan pertama yaitu bermain pantulan merupakan permainan yang mempelajari sikap awalan dan pergerakan lengan, pada saat servis maka tubuh akan posisi saat servis sebagai sikap awalan kemudian saat gerakan meraup secara otomatis lengan akan bergerak dari 
atas ke bawah sama seperti saat melakukan servis.

Berdasarkan hasil penelusuran pustaka baik cetak maupun online, maka ditemukan penelitian yang relevan dengan penulisan ini, yaitu: Imas Rokasih. 2011. Pembelajaran servis atas bola voli melalui target dinding pada kelas IV SD Negeri Lembursitu Kecamatan Sumedang Utara Kabupaten Sumedang. Pembelajaran mengenai servis atas di perbaiki dan mampu memperlihatkan hasil yang baik. Hal tersebut dapat dilihat dari persentase di data awal yang bermula sebesar $20 \%$ meningkat menjadi 64\% di siklus I berlanjut di siklus II sebesar $80 \%$ dan berakhir tuntas pada angka persentase sebesar $85 \%$ di siklus III. Dengan demikian, dapat disimpulkan bahwa media target dinding dapat meningkatkan kemampuan siswa dalam melakukan servis atas pada permainan bola voli.

\section{METODOLOGI PENELITIAN}

Desain Penelitian yang digunakan adalah penelitian eksperimen. Iskandar (2012: 20) mengatakan penelitian eksperimen adalah merupakan suatu penelitian yang menuntut peneliti memanipulasi dan mengedepankan satu atau lebih variabel bebas serta serta mengamati variabel terikat, untuk melihat perbedaan sesuai dengan manipulasi variabel bebas (independent) tersebut atau peneliti yang melihat hubungan sebab akibat kepada dua atau lebih variabel dengan memberikan perlakuan lebih (treatment) kepada kelompok eksperimen.

Desain penelitian yang digunakan pada penelitian ini dengan menggunakan “One Group Pretest-Posttest Design”, yaitu desain penelitian yang terdapat pretest sebelum diberi perlakuan dan posttest setelah diberi perlakuan, dengan demikian dapat diketahui lebih akurat. Penelitian ini akan membandingkan hasil pretest dan posttest pengaruh permainan bola pantul terhadap kemampuan servis siswa SMPN 2 Nanga Pinoh.

"Populasi adalah wilayah generalisasi yang terdiri atas objek atau subjek yang mempunyai kualitas dan karakteristik tertentu yang ditetapkan oleh penulis untuk dipelajari dan kemudian ditarik kesimpulannya". Populasi dalam penelitian ini adalah siswa-siswi SMPN 2 Nanga Pinoh dengan jumlah 19 siswa. "Sampel adalah bagian dari jumlah populasi”, Sugiyono (2011: 118). Sampel dalam penelitian ini yaitu siswa SMPN 2 Nanga Pinoh.

Teknik pengumpulan data yang dipergunakan untuk mengukur kemampuan servis atas adalah: teknik non tes, teknik nontes menggunakan lembar observasi. Cara mendapatkan datanya yaitu dengan melakukan observasi. "Validitas adalah keadaan yang menggambarkan tingkat instrumen yang bersangkutan mampu mengukur apa yang diukur". Validitas yang dipergunakan pada penelitian ini adalah 
validitas isi. Jakni (2016: 120) mengatakan validitas isi adalah pengujian validitas dilakukan atas isinya untuk memastikan apakah butir tes mengukur secara tepat keadaan yang ingin di ukur.

Analisis data merupakan tindakan untuk mengolah data menjadi informasi, baik yang disajikan dalam bentuk angka maupun bentuk narasi yang bermanfaat untuk menjawab masalah dan sub masalah dalam suatu penulisan ilmiah, Jakni (2016: 99). Dalam penelitian berdasarkan masalah apakah terdapat pengaruh media bola pantul terhadap kemampuan servis atas pada permainan bola voli pada siswa SMPN 2 Nanga Pinoh, maka untuk melihat pengaruhnya, peneliti menggunakan uji perasyaratan analisis dan uji hipotesis, yaitu: Uji persyaratan analisis yang dipergunakan adalah uji Lilliefors untuk mengetahui apakah data hasil penelitian berdistribusi normal atau tidak dan menghitung nilai ratarata dari data hasil penelitian. Uji normalitas dilakukan berfungsi untuk mengetahui apakah data yang diambil berasal dari populasi yang berdistribusi normal atau tidak. Pada penelitian ini untuk menguji normal atau tidaknya data sampel yang digunakan, maka peneliti menggunakan uji Lilliefors.

Uji hipotesis adalah cara yang dilakukan untuk menjawab pertanyaan dari rumusan masalah pada penelitian. Uji hipotesis pada penelitian ini menggunakan pengujian hipotesis Asosiatif (hubungan), karena yang akan di uji adalah hubungan atau pengaruh dari permainan bola pantul terhadap servis bola atas. Menurut Sugiyono (2011: 255) pengujian hipotesis asosiatif menggunakan rumus korelasi product moment. Setelah dilakukan pengujian hipotesis, maka hasil $\mathrm{r}$ hitung dilihat tingkat hubungannya dengan memberikan interprestasi koofisien korelasi.

\section{HASIL DAN PEMBAHASAN}

Penelitian ini dilakukan untuk melihat pengaruh permainan bola pantul terhadap kemampuan servis atas bola voli pada siswa SMPN 2 Nanga Pinoh. Penelitian ini dilakukan di luar kelas pada saat kegiatan ekstra kurikuler sekolah yang dilaksanakan tiga kali dalam seminggu selama tiga minggu. Kegiatan ekstra kurikuler ini diikuti oleh siswa yang berminat terhadap bola voli, baik siswa putra dan putri dan berbeda kelas. Sehingga kegiatan ini tidak dibatasi baik tingkat kelas maupun jumlah siswa yang mengikuti kegiatan ekstra kurikuler bola voli.

Prosedur pelaksanaan penelitian adalah dilakukan pretest pada siswa saat kegiatan ekstrakurikuler voli sebanyak 19 siswa. Terdiri dari 8 siswa putra dan 11 siswa putri. Pretest dilaksanakan pada tanggal 08 Juli 2019, pukul 15.00 wib sampai selesai. Kemudian dilakukan latihan permainan bola pantul selama tiga minggu, dengan tiga kali pertemuan setiap 
minggunya, setelah itu pada tanggal 03 Agustus 2019 diberikan posttest.

Instrumen yang dipergunakan untuk mengamati keterampilan siswa dalam servis atas bola voli yaitu dengan lembar observasi pada saat pretest dan posttest, kemudian untuk mengamati hasil kemampuan servis atas bola voli yaitu dengan mengamati dan melihat dengan seksama pada saat siswa melalukan servis atas di lapangan, karena yang dilihat dan dinilai adalah jatuhnya bola pada petak di lapangan yang sudah ditentukan skor nilainya.

Hasil pretest yang telah dilakukan terhadap kemampuan servis atas bola voli siswa diperoleh jumlah nilai 741 dengan nilai rata-rata 39 dan hasil postest diperoleh jumlah nilai 1337 dengan nilai rata-rata 70,37. Kemudian pada hasil observasi terhadap keterampilan servis atas bola voli siswa diperoleh data dengan jumlah 768 , nilairata-rata pretest 40,42 . Nilai tertinggi sebesar 57 dan nilai terendah 33. Sedangkan hasil observasi terhadap keterampilan servis atas bola voli siswa diperoleh jumlah 1358 dengan nilai rata-rata 71,47 . Nilai tertinggi sebesar 87 dan nilai terendah adalah 60 .

Berdasarkan hasil penelitian dari pretest dan postest, maka dapat disimpulkan bahwa permainan bola pantul yang telah dilakukan selama tiga minggu dengan pertemuan setiap minggunya tiga kali, ternyata pada saat postest dilakukan ternyata permainan bola pantul sangat berbengaruh terhadap kemampuan servis atas bola voli pada siswa SMPN 02 Nanga Pinoh dengan hasil yang memuaskan pada kegiatan ekstrakurikuler di sekolah.

Data hasil penelitian pretest merupakan tes langsung kemampuan servis atas bola voli siswa yang dilakukan di lapangan voli pada saat kegiatan ekstra kurikuler di SMPN 02 Nanga Pinoh pada pukul 15.00 wib, yang diikuti oleh 19 orang siswa putra dan putri dengan beragam tingkatan kelas. Berdasarkan hasil pretest dari kemamapuan servis atas bola voli masih sangat rendah, nilai tertinggi siswa adalah 60 dan nilai terendah 27, dengan jumlah nilai keseluruhan adalah 741 , dan nilai ratarata 39, dengan rincian terdapat 3 siswa memperoleh nilai 27 , terdapat 5 siswa memperoleh nilai 33 , terdapat 5 siswa dengan nilai 40, terdapat 5 siswa dengan nilai 47 dan sati siswa memperoleh nilai 60 . Dari hasil pretest kemampuan servis atas bola voli, maka dapat disimpulkan bahwa kemampuan servis atas siswa belum baik dan masih rendah.

Perolehan nilai pretest siswa dari kemampuan servis atas bola voli pada kegiatan ekstra kurikuler di SMPN 02 Nanga Pinoh dapat dijelaskan bahwa diperoleh jumlah nilai sebesar 768 dan nilai rata-rata 40,42, dengan rincian terdapat 3 orang dengan nilai 33 , terdapat 8 siswa dengan nilai 37, terdapat 2 siswa dengan nilai 40 , terdapat 2 siswa dengan nilai 43 , 
terdapat 1 siswa dengan nilai 47, terdapat 1 siswa dengan nilai 50 , terdapat 1 siswa dengan nilai 53, dan terdapat 1 siswa dengan nilai 57. Dengan demikian dapat disimpulkan bahwa keterampilan siswa dalam servis atas bola voli masih sangat rendah.

Hasil penelitian posttest merupakan tes kemampuan servis atas bola voli siswa yang dilakukan di lapangan voli pada saat kegiatan ekstra kurikuler di SMPN 02 Nanga Pinoh yang dilaksanakan setelah melakukan latihan permainan bola pantul selama tiga minggu, yang diikuti oleh 19 orang siswa putra dan putri dengan beragam tingkatan kelas.

Nilai posttest siswa dari kemampuan servis atas bola voli pada kegiatan ekstra kurikuler di SMPN 02 Nanga Pinoh dijelaskan bahwa hasil posttest dari kemamapuan servis atas bola voli masih sangat rendah, nilai tertinggi siswa adalah 87 dan nilai terendah 60, dengan jumlah nilai keseluruhan adalah 1337 dan nilai rataratanya 70,37, dengan rincian terdapat 3 siswa memperoleh nilai 27 , terdapat 5 siswa memperoleh nilai 33 , terdapat 5 siswa dengan nilai 40 , terdapat 5 siswa dengan nilai 47 dan sati siswa memperoleh nilai 60 . Jadi dapat disimpulkan bahwa kemampuan servis atas siswa sudah menjadi lebih baik pada posttest akibat dari pengaruh permainan bola pantul yang dilakukan.
Perolehan nilai posttest siswa dari keterampilan servis atas bola voli pada kegiatan ekstra kurikuler di SMPN 02 Nanga Pinoh dapat dijelaskan bahwa diperoleh jumlah nilai sebesar 1358 dan nilai rata-rata 71,47 , dengan rincian terdapat 1 orang dengan nilai 60 , terdapat 11 siswa dengan nilai 67 , terdapat 3 siswa dengan nilai 73 , terdapat 1 siswa dengan nilai 74 , terdapat 2 siswa dengan nilai 80 , terdapat 1 siswa dengan nilai 87. Dengan demikian dapat disimpulkan bahwa keterampilan siswa dalam servis atas bola voli sudah sangat lebih baik dari sebelumnya.

Analisis data dilakukan untuk mengetahui hasil dari penelitian sudah sesuai dengan yang diinginkan atau belum. Jika belum diperlukan tindakan ulang atau perbaikan dan jika sudah berhasil maka tidak perlu tindakan selanjutnya. Analisis yang dilakukan dalam penelitian ini adalah untuk mengetahui data normal atau tidak, kemudian mencari nilai rata-rata dan menguji hipotesis untuk menjawab rumusan masalah dari penelitian. Berikut analisis data tersebut, yaitu:

Uji normalitas dilakukan untuk mengetahui apakah data hasil penelitian berdistribusi normal atau tidak, maka untuk mengetahui hal tersebut maka dilakukan dengan menggunakan uji lilliefors. Apabila $\mathrm{L}_{\text {hitung }}<\mathrm{L}_{\text {tabel }}$ maka sampel data berasal dari populasi yang berdistribusi normal. Lhitung adalah nilai terbesar dari $\mathrm{F}\left(\mathrm{Z}_{\mathrm{i}}\right)-\mathrm{S}\left(\mathrm{Z}_{\mathrm{i}}\right)$, maka 
diperoleh $\mathrm{L}_{\text {hitung }}=0,3913$ dan $\mathrm{L}_{\text {tabel }}=0,235$. Jadi berdasarkan hasil tersebut maka dapat disimpulkan $\mathrm{L}_{\text {hitung }}>\mathrm{L}_{\text {tabel, }}$ maka Ho diterima dan data dikatakan berdistribusi tidak normal.

Nilai rata-rata pretest kemampuan servis atas bola voli. Nilai rata-rata hasil pretest $=39$. Nilai rata-rata pretest keterampilan servis atas bola voli $=40,42$. Nilai rata-rata posttest kemampuan servis atas bola voli $=70,37$. Nilai rata-rata posttest keterampilan servis atas bola voli $=$ 71,47

Uji hipotesis dilaksanakan untuk menjawab rumusan masalah dengan perhitungan korelasi product moment, untuk melakukan pengujian hipotesis adalah $\mathrm{Ha}=$ terdapat hubungan atau pengaruh yang signifikan antara permainan bola pantul dengan kemampuan servis atas bola voli. Ho =tidak terdapat hubungan yang signifikan antara permainan bola pantul dengan kemampuan servis atas bola voli.

Untuk melakukan uji hipotesis digunakan asumsi apabila $r_{\text {hitung }}>r_{\text {tabel }}$, maka Ha diterima dan Ho ditolak. Apabila $\mathrm{r}_{\text {hitung }}<$ $\mathrm{r}_{\text {tabel, }}$ maka Ha ditolak dan Ho diterima. Hasil perhitungan di atas diperoleh bahwa nilai $r_{\text {hitung }}\left(r_{x y}\right)$ adalah 0,9893 dan nilai $r_{\text {tabel }}$ (lihat tabel harga $\mathrm{r}$ korelasi product moment dengan $n=19$ dengan interval kepercayaan 95\%, dan taraf signifikan 5\%) maka $\mathrm{r}_{\text {tabel }}$ 0,456 , jadi dapat disimpulkan bahwa $\mathrm{r}_{\text {hitung }}>$ $\mathrm{r}_{\text {tabel, }}$ atau 0,9893>0, 456 berarti $\mathrm{Ha}$ diterima dan Ho ditolak. Jadi terdapat hubungan atau pengaruh yang signifikan antara permainan bola pantul dengan kemampuan servis atas bola voli. Hubungan atau pengaruh kedua variabel tersebut berdasarkan tolak ukur tergolong sangat kuat berdasarkan kriteria tingkat hubungan koofisien korelasi product moment.

Penelitian jenis eksperimen ini dilakukan untuk melihat pengaruh permainan bola pantul perhadap kemampuan servis atas bola voli siswa SMPN 02 Nanga Pinoh pada kegiatan ekstra kurikuler yang dilakukan tiga kali dalam seminggu. Pertemuan pertama diberikan pretest terhadap siswa yang memilih kegiatan ekstra kurikuler bola voli. Kemudian latihan permainan bola pantul selama tiga minggu, permainan bola pantul yang dimaksudkan adalah siswa memantulkan bola ke dinding dengan teknik yang diberikan untuk meningkatkan kemampuan siswa dalam melakukan servis atas. Pada pertemuan terakhir diberikan posttest untuk melihat perubahan kemampuan siswa sebelum dan sesudah diberikan latihan permainan bola pantul.

Berdasarkan hasil penelitian, pada prestest yang diberikan kemampuan dan keterampilan dalam melakukan servis atas masih banyak sekali terdapat kesalahan teknik servis atas, baik dari posisi kaki, tangan dan tubuh. Hal ini yang menyebabkan hasil observasi pretest yang 
diperoleh masih rendah. Namun setelah dilakukan latihan permainan bola pantul selama hampir satu bulan, maka teknik siswa dalam melakukan servis atas melalui permainan bola pantul sudah ada perubahan dan menjadi lebih baik.

Hasil observasi pada kemampuan dan keterampilan servis atas siswa dianalisis sehingga dapat diketahui hasil akhirnya. Setelah data diperoleh dilakukan uji normalitas dengan sampel yang kecil menggunakan uji lilliefors data berdistribusi tidak normal, karena data hasil $\mathrm{F}\left(\mathrm{Z}_{\mathrm{i}}\right)-\mathrm{S}(\mathrm{Zi})$ atau Lhitung hasilnya lebih besar dari $\mathrm{L}_{\text {tabel, }}$ atau $\mathrm{L}_{\text {hitung }}=0,3913$ dan $\mathrm{L}_{\text {tabel }}=0,235$.

Kemudian data dihitung nilai rataratanya untuk mengetahui nilai siswa secara keseluruhan. Data diolah lagi menggunakan uji korelasi product moment untuk menguji hipotesis penelitian atau menjawab dari rumusan masalah. Setelah dihitung maka diperoleh $\boldsymbol{r}_{\text {hitung }}>\mathrm{r}_{\text {tabel}}$, atau 0,9893>0,456 berarti $\mathrm{Ha}$ diterima dan Ho ditolak. Jadi terdapat hubungan atau pengaruh yang signifikan antara permainan bola pantul dengan kemampuan servis atas bola voli. Hubungan atau pengaruh kedua variabel tersebut berdasarkan tolak ukur tergolong sangat kuat.

\section{Simpulan}

Hasil perhitungan di atas diperoleh bahwa nilai $\mathrm{r}_{\text {hitung }}$ (rxy) adalah 0,9893 dan nilai $r_{\text {tabel }}$ (lihat tabel harga $r$ korelasi product moment dengan $\mathrm{n}=19$ dengan interval kepercayaan 95\%, dan taraf signifikan 5\%) maka rtabel 0,456, jadi dapat disimpulkan bahwa $\mathbf{r}_{\text {hitung }}>\mathbf{r}_{\text {tabel }}$, atau 0,9893 $>$ 0, 456 berarti Ha diterima dan Ho ditolak. Jadi terdapat hubungan atau pengaruh yang signifikan antara permainan bola pantul dengan kemampuan servis atas bola voli. Pengaruh kedua variabel tersebut berdasarkan tolak ukur tergolong sangat kuat. Berdasarkan hasil penelitian maka dapat disimpulkan bahwa terdapat pengaruh permaian bola pantul terhadap kemampuan servis atas pada permainan bola voli pada siswa SMP N 2 Nanga Pinoh.

\section{DAFTAR PUSTAKA}

PP.PBVSI, Bidang Wasit . 2004. Peraturan Permainan Bola Voli Internasional. Jakarta: PP.PBVSI.

Durwachter. 1990. Bola Volley: Belajar dan Berlatih Sambil Bermain. Diakses dari

http://Yohanes\%20Aji\%Nugroho_0860 1244020.pdf

Jakni. 2016. Metodologi Penulisan Eksperimen Bidang Pendidikan. Bandung: Alfabeta.

Kurniawan, Feri. 2012. Buku Pintar Pengetahuan Olahraga. Jakarta: Laskar Aksara.

Muhajir. 2016. Pendidikan Jasmani, Olahraga, dan Kesehatan. Jakarta: Penerbit Erlangga.

Mikanda. 2014. Buku Super Lengkap Olahraga. Jakarta: Dunia Cerdas. 
Jurnal Pendidikan Jasmani Kesehatan dan Rekreasi(Penjaskesrek)

Volume 7, Nomor 1, Januari 2020

Sugiyono. 2011. Metode Penelitian Pendidikan Pendekatan Kuantitatif, Kualitatif, dan $R$ \& D. Bandung: Alpabeta.
Sukadiyanto.2002. Teori-teori Latihan.

Diakses dari http://eprints.uny.ac.id/7715/3/BAB \%202\%20-\%2008603141034.pdf 